9. Makovetska-Hudz Yu. A. Ukrainska mova v sotsialnykh merezhakh [Elektronnyi resurs] / Rezhym dostupu: http://philology.knu.ua/files/library/movni_i_konceptualni/47-1/77.pdf (data zvernennia: 17.07.2019).

10. Ohiienko I. Nauka pro ridnomovni oboviazky. Kyiv: Oberehy, 1994. $44 \mathrm{~s}$.

11. Peretokina V. F. Anhliiskyi molodizhnyi slenh ta yoho pereklad. Anhlistyka ta amerykanistyka. Dnipropetrovskyi natsionalnyi universytet imeni Olesia Honchara. 2013. Vypusk 10. S. 129-133.

12. Pyrkalo S. Slenh: nenormatyvno, ale normalno. Urok ukrainskoi. 2000. № 4. S. 26-28.

13. Radchuk V. Surzhyk yak nedopereklad. Ukrainska mova ta literatura v shkoli. 2000. № 2. S.

14. Selivanova O. Suchasna linhvistyka : terminolohichna entsyklopediia. Kyiv, 2006. $716 \mathrm{~s}$.

15. ClovOpys [Elektronnyi resurs]. Rezhym dostupu: https://www.youtube. com/watch? $v=\mathrm{eKdHwBISs0I}$ (data zvernennia: 18.07.2019).

16. Stavytska L. Arho, zharhon, slenh. Kyiv: Krytyka, 2005. 494 s.

17. Uzdynskaia E. V. Semantycheskoe svoeobrazye sovremennoho zharhona. Saratov, 1991. $210 \mathrm{~s}$.

18. Ukrainskyi pravopys. https://zakonodavstvo.com/ministriv-kabineta-postanovi/ postanova-vidtravnya-2019-437-pitannya-2019-71792.html. (data zvernennia: 18.07.2019).

19. Chemerkin S. H. Ukrainska mova v Interneti: pozamovni ta vnutrishno-strukturni protsesy. Kyiv, 2009. $240 \mathrm{~s}$.

Одержано статтю: 15.10 .2019

Прийнято до друку: 5.11.2019

УДК $378.016: 338.46$

DOI: $10.15330 /$ esu. 17.236-244

\author{
Юрій Завалевський, \\ доктор педагогічних наук, професор, \\ Інститут модернізації змісту освіти \\ (м. Київ, Україна) \\ Yurii Zavalevskyi, \\ Doctor of pedagogical sciences, Professor, \\ Institute of Education Content Modernization \\ (Kyiv, Ukraine) \\ zuil@imzo.gov.ua
}

\title{
ФОРМУВАННЯ КОНКУРЕНТОСПРОМОЖНОСТІ МАЙБУТНЬОГО ФАХІВЦЯ СФЕРИ ПОСЛУГ
}

\section{FORMING OF COMPETITIVENESS OF THE FUTURE SPHERE OF SERVICES SPECIALIST}

Дослідження сфокусовано на з'ясування особливостей формування конкурентоспроможності майбутнього фахівия сфери послуг в сучасних закладах професійнотехнічної освіти. Зауважено на необхідності подолання суперечності між важливістю подолання потреби економіки у конкурентоспроможних кваліфікованих робітниках $i$ недостатнім теоретико - методичним забезпечениям педагогічного прочесу формувания иієї якості у майбутніх фахівиів сфери послуг. Зроблено висновок про те, ио професійнотехнічним закладам освіти потрібно формувати систему зазначених ключових якостей майбутнього конкурентоспроможного фахівия сфери послуг та створювати освітні умови за яких буде формуватися його конкурентоспроможність.

Ключові слова: конкурентоспроможність, конкурентоспроможна особистість майбутнього фахівця, фахівечь сфери послуг, соціальні особистісні якості фахівия, психологічних, когнітивних та поведінкові якості.

The research is focused on researching the peculiarities of the competitiveness formation of the future professional of the service industry at modern vocational education establishments. The necessity of overcoming the contradiction between the importance of meeting the needs of the economy in competitive skilled workers and insufficient theoretical and methodological support of 
the pedagogical process of formation of this quality with the future professionals of the service industry is emphasized.

The cognitive aspect of the system includes such characteristics as analyticity, reflexivity, speed of response, creativity, observation, criticality and integrity of thinking. It is proved that analytical thinking contributes to competitiveness as the professional is able to solve complex problems more efficiently and quickly (vital, professional, etc.); make correct, logically sound conclusions even in the absence of information; look at the problem from different perspectives and find the best variant of its decision. The basis of reflection is the mechanism of understanding by the future professional of their own motives, actions and results obtained, the ability to adequately diagnose their actions and actions of the team members, predict their own personal and professional growth.

Critical thinking as a characteristic of the cognitive aspect of the system is understood as the desire for the validate and justify their ideas and considerations, and the integrity of thinking as the ability of a professional to navigate a problematic situation using special intellectual abilities.

It is concluded that vocational education institutions need to form a system of these key characteristics of a future competitive professional in the service industry and create educational conditions under which its competitiveness will be formed.

Key words: competitiveness, competitive personality of the future professional, professional of the service industry, social and personal characteristics of the professional, psychological, cognitive and behavioral characteristics.

\section{Постановка проблеми у загальному вигляді та зв'язок із важливими науковими чи практичними завданнями.}

Сучасній економіці України необхідні фахівці 3 новим знанням, новими компетентностями, вміннями та навичками управління для успішного здійснення реформ. На різних історичних етапах розвитку суспільства, у змінах суспільноекономічних формацій завжди гостро стояла потреба висококваліфікованого, професійно компетентного фахівця. При розробці програм закладам освіти необхідно чітко усвідомлювати, що необхідною $є$ підготовка фахівця здатного відповідати вимогам часу, бути конкурентоспроможним на ринку праці та не тільки відповідати вимогам сьогодення, але й орієнтуватися на виклики майбутнього. Одним 3 найважливіших критеріїв діяльності закладу освіти $€$ якість його готового продукту, товару, випускника - майбутнього фахівця.

Виходячи із загального банку вакансій кваліфікованих робітників у розрізі різних професій, на вітчизняному ринку праці найбільшою $є$ потреба у робітниках сфери послуг: барменах, екскурсоводах, листоношах, менеджерах, модельєрах, офіціантах, охоронцях, перукарях, швачках тощо.

У зв'язку з цим аналітики констатують таку суперечність: державне замовлення на підготовку кваліфікованих робітників у професійно-технічних закладах освіти за вказаними професіями відповідає обсягам ліцензійного випуску по обраній спеціальності потребам ринку праці, проте якість підготовки у цих закладах освіти майбутніх фахівців часто не відповідає вимогам роботодавців, а тому вони стають не конкурентоспроможними на ринку праці і тому не можуть претендувати на вільні робочі місця [2, с. 165].

Аналіз ефективності працевлаштування випускників професійно-технічних навчальних закладів доводить, що більшість із них не відповідають критерію конкурентоспроможності. На тлі ринкових відносин в економічній галузі особливої актуальності набуває питання педагогічного забезпечення конкурентоспроможності майбутніх кваліфікованих робітників. Водночас у сфері професійно-технічної освіти 
спостерігається суперечливість між необхідністю задовольняти потребу економіки у конкурентоспроможних кваліфікованих робітниках і недостатнім теоретико-методичним забезпеченням педагогічного процесу формування цієї якості робітничих кадрів різного профілю. Тому перед навчальним закладом постало завдання теоретичного обгрунтування цього процесу та розроблення на цій основі педагогічного супроводу формування конкурентоспроможних кваліфікованих майбутніх фахівців.

Аналіз останніх досліджень і публікацій, в яких розглядалися аспекти цієї проблеми і на яких обгрунтовусться автор; виділення невирішених раніше частин загальної проблеми.

Поняття “конкурентоспроможність" прийшло в педагогіку з економіки і стало використовуватися відносно особистості людини. Для конкурентоспроможної особистості домінуючим $є$ наявність більш високого рівня творчого мислення, відомого як латеральне мислення (здатність відмовитись від стереотипів, здатність поглянути на проблему 3 іншого боку, здатність прийняти неочевидне рішення). Конкурентоспроможність - це новий якісний стан фахівця, який можна віднести до сфери головних стратегічних цінностей особистості. Вона сприяє подоланню індивідуального психологічного бар`єру, песимізму, невизначеності життєвих перспектив. Конкурентоспроможність упорядковує всю систему життєдіяльності індивіда в умовах ринкових відносин та економічної кризи і допомагає успішно вийти зі складних життєвих ситуацій.

Останнім часом у вітчизняній педагогічній науці спостерігається тенденція до зростання кількості наукових праць у пошуках різноманітних підходів, механізмів, аспектів конкурентоспроможності у сфері освіти, в тому числі і випускників закладів освіти на ринку праці. Але ці дослідження пов'язані, як правило, 3 окремими напрямами підготовки фахівців і присвячені питанням формування професійної компетентності (М. Вачевський, Л. Дибкова, Л. Карпова, Г. Копил, В. Костенко, В. Петрук, Н. Уйсімбаєва та ін.), навчально-пізнавальної діяльності (Г. Костишина, С. Кустовський, О. Серняк та ін.), професійної підготовки (О. Романовська, А. Андрощук, Л. Влодарська-Зола, О. Куліш, О. Москалюк, Е. Нероба, О. Шупта, Л. Щербатюк та ін.), готовності до професійної діяльності (О. Бойко, О. Демченко, С. Доценко, Л. Гончаренко, В. Іванова, М. Карченкова, О. Макаренко, В. Пліско, Г. Савченко, Т. Шестакова та ін.), адаптації до професійної діяльності (Я. Абсалямова, С. Гура, Л. Зданевич, Т. Кухарчук, С. Хатунцева, В. Цибулько, Н. Шапошнікова та ін.).

Визначаючі конкурентоспроможність як важливу характеристику особистості, зарубіжні вчені також пов'язують іiі з такими категоріями, як самоактуалізація (А. Маслоу, Ф. Перл), стратегія виграшу (М. Джеймс, Д. Джонгвард), здатність до самоствердження й самонавчання (Е. Мелібруда, К. Роджерс), асертивність (самостверджувальна поведінка) (Р. Алберті, В. Каппоні, Т. Новак, М. Еммонс), життєва успішність (В. Біркенбіл), сенсожиттєва орієнтація, конгруєтність (М. Перл, В. Франкл).

М. Варій називає конкурентоспроможним фахівцем особистість, яка “здатна швидко й безболісно адаптуватися до постійних змін суспільних умов, науково-технічного прогресу й нових видів діяльності та форм спілкування за умови збереження позитивного внутрішнього психоенергетичного потенціалу й гармонії [2].

М. Кононець пов'язує конкурентоздатність 3 професійною соціалізацією особистості [5]. Л. Карамушка, О. Філь визначають конкурентоздатність як важливу складову розвитку професіоналізму особистості і у якості їі головних характеристик 
називають потребу в досягненнях (подальшому розвитку), схильність до творчості, цілеспрямованість та рішучість, вміння йти на розумний (зважений) ризик, потребу в незалежності/автономії, які забезпечують іï ефективну конкуренцію на сучасному ринку праці [4].

Л. Галаган конкурентоздатність особистості розуміє як їі здатність до успішної конкурентної взаємодії, що визначається психологічними характеристиками особистості, характеризується відносністю, динамічністю, індивідуальністю та активним саморозвитком [3]

У дослідженнях А. Алєксєєвої, професійна конкурентоздатність особистості визначається орієнтацією на успіх, комунікативною компетентністю, автономністю, толерантністю до невизначеності, прагненням до статусного росту, адекватною схильністю до ризику та здатністю до самоактуалізації [1]

Виклад основного матеріалу дослідження 3 повним обгрунтуванням отриманих наукових результатів.

У процесі професійної підготовки майбутніх фахівців сфери послуг слід звертати належну увагу на розвиток внутрішніх факторів (мотиваціі), на які активно впливає родина та зовнішнє середовище. Мотиваційний компонент готовності студентів до професійної діяльності стимулює їх до набуття професійних знань, необхідних для здійснення цісї діяльності. Лише за умови наявності позитивної мотивації в процесі навчальної діяльності, можна досягти результатів у професійному розвитку особистості, набутті ним певних професійних знань, вмінь і навичок, отримати необхідні якості особистості.

Уважаємо, що майбутній конкурентоспроможній фахівець має володіти професійними, демографічними, освітньо-кваліфікаџійними та соџуіальними якостями; соцуіальні якості, в свою чергу, складаються з психологічних, когнітивних та поведінкових. Саме соціальні якості особистості відіграють важливу роль у формуванні конкурентоспроможності майбутнього фахівця сфери послуг, тому схарактеризуємо їх більш детально.

Важливо зазначити, що на конкурентоспроможність майбутнього фахівця впливають соціально-особистісні характеристики, які виражаються в особливостях психології, розуму і поведінці особи в суспільстві, рисах характеру, професійному та трудовому потенціалі.

Значущими психологічними рисами у формуванні конкурентоспроможності фахівця є, на наш погляд. емпатія, емоиійність, автентичність, відкритість, толерантність, терплячість, розвинута інтуйція та стійкість до стресу. Емпатія - це соціально-психологічна властивість особистості, яка складається 3 ряду здатностей: здатність емоційно реагувати і відкликатися на переживання іншого, здатність розпізнавати емоційний стан іншого і ніби переносити себе в його думки, почуття i дії; здатність давати адекватну відповідь як вербального, так і невербального типу на переживання іншого. В останні роки проблема емпатії розглядається і в професійному контексті як одна $з$ найважливіших властивостей у структурі особистості професіонала.

Наступною важливою якістю особистості людини, що впливає на іiі конкурентоспроможність, є емоційність, яка виявляється в силі характеру та спрямованості їі емоцій. Під емоціями розуміють чуттєву реакцію людини на зовнішній вплив (позитивні й негативні емоціі).

Aвтентичність - це поняття, що запозичене з екзистенціалістської філософії, та пов'язане 3 проблемами самовизначення i самоконституювання конкурен- 
тоспроможного фахівця, характеру зумовленості здійснених ним виборів i можливості бути автором власного життя, володіти власним буттям, яке отримало найбільш детальну розробку в працях М. Хайдеггера і Ж. П. Сартра. Головним у цій якості відкритість є готовність, бажання і здатність людини психологічно відчувати i розуміти іншого, дивитися на світ його очима, на час, забуваючи про своє сприйняття світу, про свою власну точку зору.

Толерантність уважаємо умінням (здатністю і прагненням) майбутнього конкурентоспроможного фахівця вибудовувати конструктивні стосунки 3 людьми, шо відрізняються по яким-то ознакам (світоглядним, національним, конфесійним і тому подібне) спираючись на розуміння і доброзичливе прийняття відмітних особливостей, визнання людини головною гуманістичною цінністю, пошану людської гідності.

Терплячість визначаємо як уміння конкурентоспроможного майбутнього фахівця підтримувати шляхом допоміжного вольового зусилля інтенсивність роботи на заданому рівні за умов виникнення внутрішніх перешкод (наприклад, якщо $\epsilon$ втома, поганий настрій, за незначних хворобливих проявів).

Варто зазначити, що на конкурентоспроможність впливає також розвинута інтуїція, оскільки на інтуїтивному рівні майбутній фахівець виявляє сукупність “передпрофесійних" умінь. Приступаючи до вирішення професійної проблеми, він не усвідомлює їі навіть як задачу, а діє інтуїтивно, часто не вміючи пояснити, чому робить щось саме так, а не інакше, і чого прагне досягти.

Наступною важливою психологічною характеристикою майбутнього конкурентоспроможного фахівця є стійкість до стресу. Це - структурно-функціональна, динамічна, інтегративна властивість, що з'являється як результат трансактного процесу зіткнення особистості зі стресогенним фактором, включає когнітивну репрезентацію, об’єктивну характеристику ситуації та вимоги до особистості. Адекватність оцінки ситуації та власних ресурсів визначає інтенсивність реакцій, спрямованих майбутнім фахівцем на зміну компонентів стресової ситуації, зміну когнітивної репрезентації, ставлення, мотиваційної, вольової орієнтації, копінгової поведінки, які здійснюються через провідну іï функцію - когнітивно-феноменологічної перспективи та функції іiі окремих структурних компонентів, що зумовлюють рівень стресостійкості під час і після травматичних подій.

Конкурентоспроможність фахівця обумовлюється також якостями, що відносяться до когнітивного аспекту (аналітичність, рефлексивність, ивидкість реакиії, креативність, спостережливість, критичність і цілісність мислення). Пояснимо ці якості більш детальніше.

Поза сумнівом, здатність мислити аналітично буде корисна кожному, але понад усе вона потрібна тим, хто хоче добитися успіху і стати першим в своїй справі. Майбутній фахівець, що володіє аналітичним складом розуму, має величезну перевагу. Він може ефективніше і швидше вирішувати складні завдання (життєві, професійні і ін.); він робить вірні, логічно обгрунтовані висновки навіть в разі недоліку відомостей; він дивиться на проблему з різних точок зору, тому здатний знайти оптимальний варіант і1і рішення; про таку особистість говорять, що він спочатку думає, а потім робить.

Основу рефлексії складають механізм осмислення майбутнім фахівцем власних мотивів, вчинків і отриманих результатів, здібності адекватної діагностики своїх дій i дій членів колективу, прогнозування власного особистісного i професійного росту. Сукупність вказаних характеристик особистості визначає i 
активізує внутрішні механізми, які коригують інші професійні і особистісні складові, завдяки чому мобілізуються резерви для розвитку формування конкурентоспроможності майбутнього фахівця.

Варто також додати інші особистісні якості, що мають можливість актуалізувати конкурентоспроможність особистості:

Швидкість реакції майбутнього фахівця визначається роботою нервової системи. Вказана якість важлива при реакції фахівця на дуже сильне роздратування, небезпечне для життя.

Рівень творчої обдарованості або здібності до творчості, творча спрямованість фахівця відображено в його креативності, яка здатна вигідно відрізняти його серед інших претендентів. Спостережливість - здатність помічати частковості, що вислизають від інших, подробиці явищ, фактів.

Важливими якостями когнітивного аспекту є також критичність $і$ йілісність мислення. Критичність мислення розуміємо як прагнення до обгрунтованості та доказовості своїх ідей і міркувань. цілісність мислення - як здатність фахівця орієнтуватися в проблемній ситуації спираючись на унікальне динамічне співвідношення діапазону трансспективи власного мислення, сили допитливості, структури загальних та спеціальних інтелектуальних здібностей, рівня обдарованості та форм мисленевих дій.

Поведінкові якості (комунікабельність, ініціативність, активність, адаптація, мобільність, здатність до імпровізації, здатність до релаксації, готовність до ризику, управлінських дій, особистісної відповідальності за результати праці) виявляються у певному особистісному алгоритмі дій відповідно досягнення фахівцем конкурентоспроможності:

Комунікабельність розуміємо як здатність і схильність, до комунікації, до встановлення контактів і зв'язків, до їх підтримки і збереження, до здійснення конструктивної взаємодії з тими, що оточують.

Iніціативність визначаємо як вміння знаходити нові, нешаблонні рішення й засоби їх здійснення. Протилежними якостями є безініціативність та залежність. Безініціативна людина легко піддається впливу інших людей, їхніх дій, вчинків, власні рішення ставить під сумнів, не впевнена в їх правильності та необхідності. Особливо виразно ці якості виявляються у формі навіювання.

Важливою поведінковою якістю уважаємо активність конкурентоспроможного майбутнього фахівця, яка визначається як активна складова діяльності людини та як така діяльність, що спрямована на предмет праці, на соціальне середовище і самого себе. У професійному співтоваристві його учасники займають однорідні соціальні позиції, мають певний професійний статус. Відповідно, ідентичність засвоєння цінностей забезпечується ідентичністю вимог, що окреслюється професійним статусом. Механізм цього процесу закладений у професійну роль, засвоєння якої дозволяє розуміти і засвоювати цінності професійної діяльності.

Свого часу А. Маслоу [7] вказував на нерозривний зв'язок особистості i професійної діяльності, зазначаючи, що в процесі професійної праці, що відбувається у певних соціально-економічних умовах, формуються не лише окремі функціональні системи і психічні процеси людини (професійне сприйняття, пам'ять, мислення і т.п.), але і його особистість, що призводить до утворення соціальнопрофесійного типу особистості з визначеними ціннісними орієнтаціями, характером, особливостями міжгрупового і внутрігрупового спілкування і т.п. 
Під такою якістю особистості як активність слід розуміти здібність робити вибір і приймати відповідальне рішення, орієнтацію на ефективність і якість, творче відношення до справи, системне бачення проблеми, а головне - це відповідність вимогам роботодавця, вмінням адаптуватися на робочому місці в умовах суперництва, адаптація - це процес пристосування фахівця до нових професійних, соціальних і організаційно-економічних умов праці, який слід характеризувати, перш за все, як процес соціальної адаптації, спрямований на набуття людиною своєї цілісності шляхом інтеграції особистісної, соціальної і культурної сфер іiі життедіяльності.

Адаптація як елемент конкурентоспроможності фахівця, визначається процесами перебудови діяльності і поведінки особистості у відповідь на нові вимоги оточуючого середовища. Це безперервні процеси оволодіння професійними і особистісними якостями для зростання конкурентоспроможності в умовах, що постійно змінюються. Результатом таких процесів $\epsilon$ формування самосвідомості і рольової поведінки, адекватних зв'язків з оточуючими, прийняття індивідом своєї соціальної ролі, а також узгодження самооцінки і прагнень особистості 3 його можливостями і 3 реальністю соціального середовища. Швидкість процесів адаптації і задоволення потреб і інтересів суб'єктів соціального середовища, зокрема роботодавців, у порівнянні з іншими, $\epsilon$ важливим показником рівня конкурентоспроможності фахівця.

Успішність адаптаційних й інших процесів значною мірою залежить від розвитку рефлексії у майбутнього фахівця, яка об'єднує компетенції самопізнання і самоаналізу цінностей, інтересів, мотивів, ефективності діяльності i вчинків особистості та наступного формування коректувального впливу на інші складові.

Ще одна не менш важлива якість у формуванні конкурентоспроможного майбутнього фахівця є мобільність. Мобільність - це сформована властивість особистості, ії готовність та здатність опановувати будь-які професійні нововведення та прагнення до зміни виду професійної діяльності. Це інтегративна характеристика особистості, що визначає успішну адаптацію до умов ринку праці та полікультурного середовища, готовність до вертикальних і горизонтальних кар'єрних переміщень і до конкурентоспроможності майбутнього фахівця на ринку праці. Уважаємо, шо основа професійної мобільності майбутнього фахівця складається 3 предметних, комунікативних, лінгво-культурологічних, спеціальних знань i здатності до їх швидкого переносу.

Управлінські дії конкурентоспроможного майбутнього фахівця розуміємо визначаємо як сукупність загально-теоретичних, спеціальних управлінських i психологічних знань, умінь і навичок, якими повинен володіти майбутній фахівець для ефективного ії здійснення й корекції. Під особистісною відповідальністю за результати праияі майбутнього фахівця розуміється як свобода вибору, волі та засобів існування або як дотримання категоричного імператива, як спосіб реалізації життєвої позиції або як спосіб самореалізації особистістю своєї сутності.

Усі зазначені складові формуються під впливом як зовнішніх чинників (культурних і релігійних традицій, соціальної та політичної стабільності, рівня грамотності та освіченості населення), так і внутрішніх (особистісних та життєвих пріоритетів, інноваційної активності, особливостях сімейного виховання тощо).

Уважаємо, що професійно-технічним закладам освіти потрібно формувати систему зазначених ключових якостей майбутнього конкурентоспроможного фахівця сфери послуг та створювати освітні умови при яких буде формуватися його конкурентоспроможність. До цих умов належить інноваційне професійне навчания, 
тобто вивчення студентами професійних інноваційних технологій, так як фахівці, в котрих сформовані уміння працювати на новій техніці та використовувати у професійній діяльності інноваційні виробничі технологіі, мають більші конкурентні переваги порівняно з тими, хто не має подібної професійної підготовки. Саме тому, первинним завдання професійно-технічних закладів освіти є моніторинг ринку праці, метою якого є вивчення інноваційних нововведень у виробничому процесі. На цьому положенні Н.Г. Ничкало акцентує увагу працівників сфери професійно-технічної освіти у такий спосіб: “головне полягає в орієнтації професійних шкіл (різного профілю й різних типів) не на просте відтворення робочої сили, а на постійний системний зв'язок 3 динамікою змін на ринку праці, секторами економіки та науково-технічним прогресом" [8, с. 135].

Висновки дослідження і перспективи подальших розвідок цього напряму.

Таким чином, формування соціальних особистісних якостей конкурентоспроможного фахівця, використання професійних інноваційних технологій у виробничому процесі та створення конкурентного навчального середовища може стати потужним каталізатором при формуванні конкурентоспроможності майбутнього фахівця. А педагогічній громадськості необхідно усвідомити актуальність цієї задачі як невід'ємної частини ефективної та сучасної професійної освіти. Перспективи подальших розвідок у розглянутому напрямі вбачаємо у розробці методичних комплексів формування психологічних, когнітивних та поведінкових якостей особистості майбутнього фахівця, які $є$ необхідною складовою його професійної конкурентоспроможності.

1. Алєксєєва А.В. Професійна конкурентоздатність особистості: психологічний аспект. Психологія праці та управління: Збірник наукових праць VI Міжнародної науково-практичної конференції: - Част. 1. -К.: ІПК ДСЗУ, 2009. - С. 147-153.

2. Варій М. Й. Загальна психологія : навчальний посібник К. : “Центр учбової літератури”, 2007. $-968 \mathrm{c}$.

3. Галаган Л. В. Психологічні особливості розвитку конкурентоздатності безробітних-майбутніх підприсмців : автореф. дис. на здобуття наук. ступеня канд. псих. наук : спец. 19.00.10 “організаційна психологія; економічна психологія". К., 2013. -22 с.

4. Карамушка Л. М., Філь О.А. Формування конкурентоздатної управлінської команди на матеріалі діяльності освітніх організацій: [монографія] К. : ІНКОС, 2007. - 268 с.

5. Кононець М.О. Професійна соціалізація студентів технічного університету як умова підвищення їх конкурентоздатності на ринку праці : Психологічні умови розвитку конкурентоздатності організації : тези VI міжнародної наук.-практ. конф. з організаційної та економічної психології (м. Керч, 25-27 червня 2009 р.) / за наук. ред. Л.М. Карамушки. - К. : Наук. світ, 2009. - С. 56-60.

6. Кримова М. О. Компетентнісна основа освітньої системи України та ії роль в формуванні конкурентоспроможності фахівця . Вісник Донецького ун-ту. Донецьк : ДонНУ. 2011. Т. 1. С. 89-91. (Серія "Економіка і право").

7. Маслоу А. Самоактуализация. Просвещенный менеджмент. Организационная теория. [ пер. с англ. Н. Левкиной, А Чеха]. - СПб. 6 Питер, 2003. - 413 с.

8. Ничкало Н. Г. Професійна освіта і навчання: проблеми взаємозв'язку з ринком праці [текст] Формування широкої кваліфікації робітників. Вклад ПТО у розвиток трудового потенціалу XXI століття: зб. матер., підгот. у рамках реалізації укр.-нім. проекту "Підтримка реформи професійно-технічної освіти в Україні" / Ю. Вайс, Н. Ничкало, А. Сімак та ін. - Ніжин: ТОВ "Видавництво “Аспект-Поліграф", 2007. - С. 134-138.

\section{References}

1. Alieksieieva A.V. Profesiina konkurentnozdatnist osobystosti: psykholohichnyi aspekt. Psykholohiia pratsi ta upravlinnia: Zbirnyk naukovykh prats VI Mizhnarodnoi naukovo-praktychnoi konferentsii: Chast. 1. -K.: IPK DSZU, 2009. - S. 147-153. 
2. Varii M. Y. Zahalna psykholohiia : navchalnyi posibnyk K. : "Tsentr uchbovoi literatury", 2007. $968 \mathrm{c}$.

3. Halahan L. V. Psykholohichni osoblyvosti rozvytku konkurentnozdatnosti bezrobitnykh-maibutnikh pidpryiemtsiv : avtoref. dys. na zdobuttia nauk. stupenia kand. psykh. nauk : spets. 19.00.10 "orhanizatsiina psykholohiia; ekonomichna psykholohiia". K., 2013. -22 s.

4. Karamushka L. M., FIl O.A. Formuvannia konkurentozdatnoi upravlinskoi komandy na materiali diialnosti osvitnikh orhanizatsii: [monohrafiia] K. : INKOS, 2007. $-268 \mathrm{~s}$.

5. Kononets M.O. Profisiina sotsializatsiia studentiv tekhnichnoho universytetu yak umova pidvyshchennia yikh konkurentozdatnosti na rynku pratsi : Psykholohichni umovy rozvytku konkurentozdatnosti orhanizatsii : tezy VI mizhnarodnoi nauk.-prakt. konf. z orhanizatsiinoi ta ekonomichnoi psykholohii (m. Kerch, 25-27 chervnia 2009 r.) / za nauk. red. L.M. Karamushky. K. : Nauk. svit, 2009. - S. 56-60.

6. Krymova M. O. Kompetentnistna osnova osvitnoi systemy Ukrainy ta yii rol $\mathrm{v}$ formuvanni konkurentospromozhnosti fakhivtsia. Visnyk Donetskoho un-tu. Donetsk: DonNU. 2011. T. 1. S. 8991. (Seriia "Ekonomika i pravo").

7. Maslou A. Samoaktualyzatsyia. Prosveshchennyi menedzhment. Orhanyzatsyonnaia teoryia. [ per. s anhl. N. Levkynoi, A Chekha]. - SPb. 6 Pyter, 2003. - 413 s.

8. Nychkalo N. H. Profesiina osvita i navchannia: problemy vzaiemozviazku z rynkom pratsi [tekst] Formuvannia shyrokoi kvalifikatsii robitnykiv. Vklad PTO u rozvytok trudovoho potentsialu KhKhI stolittia: zb. mater., pidhot. u ramkakh realizatsii ukr.-nim. proektu "Pidtrymka reformy profesiinotekhnichnoi osvity v Ukraini" / Yu. Vais, N. Nychkalo, A. Simak ta in. - Nizhyn: TOV "Vydavnytstvo "Aspekt-Polihraf", 2007. - S. 134-138.

Одержано статтю: 19.09.2019

Прийнято до друку: 17.10.2019

УДК $378.22: 373.2$

DOI: $10.15330 /$ esu. 17.244-252

\section{Неллі Лисенко,}

доктор педагогічних наук, професор,

ДВНЗ “Прикарпатський національний університет імені Василя Стефаника"

(м. Івано-Франківськ, Україна)

Nelli Lysenko,

Doctor of pedagogic sciences, Professor,

Vasyl Stefanyk Precarpathian national university

(Ivano-Frankivsk, Ukraine)

doshkilnaosvita@i.ua

\section{ПШДГОТОВКА МАГІСТРІВ - МАЙБУТНІХ ПЕДАГОГІВ ЗАКЛАДІВ ДОШКІЛЬНОЇ ОСВІТИ: ШЛЯХИ УДОСКОНАЛЕННЯ}

\section{PREPARATION OF MASTERS - FUTURE EDUCATORS OF PRESCHOOL EDUCATIONAL INSTITUTIONS: WAYS TO IMPROVE}

У статті розглядаються сучасні підходи до організачіі прочесу підготовки майбутніх педагогів для закладів дошкільної освіти (ЗДО) під час вивчення навчальних фахових дисчиплін. У числі обов'язкових фахових дисииплін “Педагогіка дошкільна", яку пролонговано вивчають від I-го (II семестр) - до III (VI семестр) курсів на денній та дистанчійній формах навчання. Ї̈ викладання спирається на низку теоретико-методологічних підходів (аксіологічний, системний, діяльнісний, компетентнісний, міждисциплінарний та ін.), що неподільно функиіонують в освітньому прочесі (ЗВО) закладів вищої освіти. Фахова дисчипліна покликана підготувати студентів до практичної діяльності з дітьми 6 руслі аксіо-гуманістичної педагогіки. У статті розлого розглянуто кончепџію фахової підготовки “навчання через завдання” і охарактеризовано ї̈ три важливі орієнтації: гуманістичну (збагачения індивідуального та особистісного потенціалу; оволодіння способами творчого самовираження і самореалізації), функціональну, технологічну. 